\title{
МЕЖІ СУДОВОГО РОЗГЛЯДУ
}

\author{
КОРЕЦЬКА Вікторія Віталіївна - суддя Ківерцівського районного суду \\ Волинської області \\ orcid.org 0000-0002-5685-5337 \\ УДК 347.93.94 \\ DOI 10.32782/LAW.2020.3.16
}

\begin{abstract}
Проведение рефбормы уголовного прочессуального законодательства предоставила новые ялементы построения уголовного процесса. Определено, что предель судебного разбирательства связанъ предварительным судебнъим производством. Процессуальнъе полномочия судъи, установленнъие действуюшим законодательством, соответствуют международнъим правовъим нормам и обеспечивают выполнение прав, свобод и гарантий участников уголовного производства. Предельг судебного разбирательства уголовного производства проводится в отношении обвиняемого в соответствии с обвинительного акта. Изменение обвинения может осуществляться публичнъм обвинителем.

Предложень теоретические аспекть и практическое решение даннъх вопросов и внесения изменений в действующее законодательство.

Ключевъе слова: границь, механизм, статус, следователь, прокурор, судья, обвиняемъий, судебное разбирательство, приговор.
\end{abstract}

Актуальність статті полягає в тому, що за чинним КПК України слідчий складає обвинувальний акт, який затверджує прокурор та направляе його до суду. Суддя, отримавши обвинувальний акт повинен розглянути його у підготовчому судовому провадженні та призначити судовий розгляд кримінального провадження. Межі підготовчого судового провадження визначені ст. 314 КПК України, однак подальший термін судового розгляду встановлений за розумними строками кримінального процесу. Тому суддя має право розглядати кримінальну справу до встановлення об'єктивної істини.

КПК України 1961 року встановлював аспекти повернення кримінальної справи для проведення додаткового розслідування, усунення прогалин досудового розслідування не на судових стадіях процесу, а на стадії досудового провадження. Прокурор під час додаткового досудового розслідування приймав рішення щодо закриття кримінального провадження.

Чинний КПК України скасував методику повернення кримінальної справи прокурору, суддя повинен на підставі судових доказів встановити обставини кримінального правопорушення. Він встановлюе вину обвинуваченого та відповідає за вирок.

Ст. 337 КПК України встановила загальні положення визначення межі доказування судового розгляду кримінального провадження, а саме судовий розгляд проводиться стосовно обвинуваченого відповідно до обвинувального акту. Однак, до кінця не визначено процедуру та механізм меж судового розгляду.

Мета статі полягає у визначенні межі судового розгляду, розкрити процедуру та механізм перевірки доказів, які знайшли свій вираз під час судового розгляду. Суддя повинен визначити межі обставин кримінального правопорушення, встановити вину обвинуваченого на підставі його показань, 


\section{Кримінальне право, кримінальний процес та криміналістика}

скласти обвинувальний вирок, а саме виконати завдання кримінального процесу.

Теоретичні положення можна встановити на підставі процесуальної діяльності суду у кримінальному процесі, яка була предметом наукових дискусій вчених, що визначали процесуальний статус судді, законність процесуальних рішень суду, встановили межі судового розгляду. Основні теоретичні розробки були наданіЮ.П. Аленіним, М.І. Бажановим, Л.О. Богословською, В.Д. Бринцевим, Е.Г. Веретехіним, Ю.М. Грошевим, О.М. Дроздовим, О.В. Капліною, В.Т. Маляренко, Д.В. Філіним, О.Г. Шило, О.Г. Яновською та ін. [1; 3; 4 , с. $206-209 ; 5$, с. $100 ; 8 ; 9 ; 12 ; 15 ; 16$, с. 15 ; 19 , c. $129 ; 20]$.

Перші положення процесуальної діяльності суду були розроблені у 1879 р. К.Д. Анціферовим, у 1898 р. В .Ф. Дерюжинським та ін., які встановили межі судового розгляду на підставі функції справедливості щодо обвинуваченого під час судового розгляду. У такому разі, якщо вирок суду відповідав наслідкам вчиненого кримінального правопорушення, то функція суду була виконана [2].

На підставі розподілу функцій у кримінальному процесі функція суду була відокремлена від процесуальної діяльності органу досудового розслідування. Суддя став самостійним під час судового розгляду та незалежним від впливу інших гілок влади.

I.В. Гловюк, Т.Н. Добровольская та ін. надали аналіз процесуальних функцій суду, на підставі яких було визначено межі судового розгляду. Вони вважали, що суддя під час судового розгляду встановлюе обставини кримінального правопорушення та докази вини обвинуваченого. Чинний КПК України встановив участь сторін під час судового розгляду кримінальної справи тому процесуальна діяльність суду є статус арбітра, який слухає висновки сторін та оцінює надані фактичні дані, що свідчать про вину, або невинуватість обвинуваченого. Межі судового розгляду встановлені обставинами кримінального правопорушення та доказами, що вказують на вину обвинуваченого $[10 ; 11]$.
М.І. Бажанов, Ю.М. Грошевой, А.Д. Зусь та ін. розглядали процесуальні межі правової діяльності суду та визначили елементи правотворчості. Окремі положення встановлення обставин кримінального правопорушення суддя повинен використовувати на підставі рішень Конституційного, Верховного, Європейського Суду з прав людини. Вирок суду повинен відповідати не тільки обставинам кримінального злочину, з точки зору матеріального права, а також основної концепції Європейської судової практики $[3 ; 9 ; 13]$.

На підтвердження цієї позиції Д.П. Великий, О.М. Овчаренко та ін. вважали, що диспозиція процесуальних норм повинна бути забезпечена примусовою силою держави. Вони вважали, що публічне та приватне право присутнє у кримінальному процесі. Публічне право захищає інтереси особи, суспільства, держави від кримінального правопорушення. Приватне право включає до себе елементи позовної заяви, яка подається учасником кримінального провадження та спрямована на захист прав, свобод, інтересів та відшкодування матеріальної шкоди $[7$, с. 10; 17].

В.T. Маляренко надав положення юридичної практики суду та вказував, що вона має наступні напрямки, зокрема орієнтує суддю для прийняття процесуального рішення та ухвалення вироку; конкретизує права та обов'язки судді для встановлення меж оцінки доказів, встановлення обставин кримінального правопорушення, визначення кваліфікації за КК України відносно обвинуваченого; інформаційні результати розгляду кримінальних проваджень Вищим Судом, отримання ухвали, рішення Верховного суду для орієнтації визначення кваліфікаційних положень вчинення кримінального правопорушення [16, с. 15].

Опоненти вважали, що процесуальна діяльність суду пов'язана не тільки обвинувальним актом, а також результатом судового розгляду клопотання слідчого, прокурора на стадії досудового розслідування. Вони звертали увагу на те, що процедура отримання ухвали слідчого судді на стадії досудового розслідування має ознаки церемонії, ніж процесуального визначення. Суддя не 
знайомиться 3 матеріалами справи, оскільки досудове розслідування має тільки початковий період, зміна обвинувачення може здійснюватися протягом усього досудового провадження. Крім того, суддя не має механізму перевірки наданої ухвали, оскільки слідчий не повідомляє судді про результати іiі виконання.

С.Б. Росінський, Д.В. Філін та ін. вважали, що слідчий суддя на стадії досудового розслідування повинен здійснювати судовий контроль за процесуальною діяльністю слідчого, прокурора. Результати виконання ухвали слідчого судді під час судового розгляду кримінального провадження повинні бути перевірені [18, с. 17; 19, с. 129].

3 даних теоретичних аспектів можна надати приклад. На підставі ст.225 КПК України, проведення допиту слідчим суддею на стадії досудового провадження. Якщо протокол допиту учасника кримінального провадження на стадії судового розгляду підлягає перевірки, то протокол допиту слідчим суддею є судовим доказом, який може бути покладений у вирок. Однак, механізм проведення даного допиту до кінця не визначено. Слідчий не може знати у який термін він повинен надати клопотання слідчому судді для проведення допиту учасника процесу. Необхідно забезпечення охорони учаснику процесу. Які межі допиту повинні бути встановлені слідчим суддею, оскільки він не володіє матеріалами кримінального провадження в повному обсягу.

\section{Виклад загального матеріалу}

Встановлення межі судового розгляду необхідно визначити на підставі загальних положень кримінального процесу. Пропонуємо наступні форми встановлення межі судового провадження. Перша форма передбачає судовий розгляд кримінальної справи, встановлення обставин кримінального правопорушення, складання вироку. Друга - зміна обвинувачення під час судового розгляду прокурором; визначення додаткового обвинувачення стороною обвинувачення; відмова від підтримання державного обвинувачення прокурором. Третя форма встановлення неповноти судового розгляду; невідповідність висновків суду, викладених у судовому рішенні, фактичним обставинам кримінального провадження; істотне порушення вимог кримінального процесуального закону; неправильне застосування закону України про кримінальну відповідальність; невідповідність призначеного покарання тяжкості кримінального правопорушення та особі обвинуваченого.

На підставі цих форм можна надати теоретичну модель статусу судді на стадії судового розгляду. Основний елемент статусу судді встановлений Конституцією України, як гілки судової, державної влади. Суддя є незалежним у своїй процесуальної діяльності та підкоряється тільки закону та виконує його. Друга конструкція статусу судді включає процесуальні аспекти, які визначені та закріплені у чинному КПК України. Процесуальні права, обов'язки судді є фундаментом для законного, неупередженого ухвалення вироку. На підставі завдань, мети кримінального процесу, які встановлені сукупністю правових елементів вини обвинуваченого, суддя повинен визначити межі обвинувачення та встановити істину.

Теоретичні та практичні проблеми кримінального процесу включають аспекти процесуальної діяльності суду під час оцінки доказів, що надані органом досудового розслідування та прокурором. Незважаючи на те, що суддя бере участь у встановленні обставин кримінального правопорушення, проводить допит учасників судового розгляду, перевіряє докази, заслуховує доводи обвинувачення з боку публічного обвинувача та доводи сторони захисту щодо оцінки доказів, які вказують на вину обвинуваченого, він пов'язаний обвинувальним актом та матеріалами кримінального провадження.

Статистичні дані Верховного Суду України вказують, що $65 \%$ органи досудового розслідування надають матеріали кримінального провадження, а під час судового розгляду суддя встановлює порушення процесуальних норм. 35\% під час судового розгляду кримінального провадження суддя встановлює неправильну кваліфікацію про кримінальну відповідальність [21].

Основна тенденція процесуальної діяльності судді полягає в тому, щоб диференціювати кримінальну відповідальність, звузити 


\section{Кримінальне право, кримінальний процес та криміналістика}

застосування репресивних заходів впливу до обвинуваченого. Тільки після ретельної перевірки обставин кримінального правопорушення суддя має право проголосити вирок. Норми чинного КПК України встановлюють предмет доказування, його межі, які є однакові для досудового та судового провадження.

Межі судового розгляду, за чинним КПК України, мають нові правові конструкції. Перша включає зміну обвинувачення під час судового розгляду прокурором, визначення додаткового обвинувачення стороною обвинувачення. Друга - відмова від підтримання публічного обвинувачення прокурором. Суддя під час судового розгляду повинен встановити два взаємопов'язані аспекти, зокрема визначити обвинувачення в цілому та визначити окремі його епізоди. Тим самим він повинен або підтвердити обвинувачення, або визначити обставини, які вказують на зміну обвинувачення прокурором.

Аналіз практики, перевірка 400 кримінальних проваджень у судах Волинської, Київської, Харківської областях свідчить про недоліки процесуальної діяльності слідчого під час складання обвинувального акту. У цьому разі можна зазначити, що у $50 \%$ випадків є порушення процедури та відсутність єдиного визначення обвинувачення, зокрема: неконкретність формулювання. 25\% можна відзначити неточність кваліфікації кримінального правопорушення. $15 \%$ - формулювання обвинувачення за обсягом і змістом відрізняється від описової частини. $10 \%$ - слідчий неправильно визначає матеріальний склад вини підозрюваного.

Практика вказує на проблеми формулювання обвинувачення 3 «деяким запасом кримінального правопорушення». Суддя змушений змінити кваліфікацію під час проголошення вироку.

\section{Висновок}

Межі судового розгляду повинні проводиться відносно обвинуваченого та на підставі обвинувачення відповідно до обвинувального акту. Зміна обвинувачення повинна мати випадковий зміст. Публічний обвинувач має право змінити обвинувачен- ня тільки, якщо воно не погіршує процесуального статусу обвинуваченого.

\section{Аітература \\ 1. Аленин Ю. П. Уголовно-} процессуальный кодекс Украины Науч. практ. комментарий / Ю. П. Аленин. Харків: Одисей, 2003. - 959 с.

2. Анциферов К. Д. Обвинительное начало и английский процесс / К. Д. Анциферов // Юридический вестник. - Москва, 1879. - С. 432.

3. Бажанов М.И. Производство дознания в органах милиции. /М.И. Бажанов, А.Д. Коган// -Х.: 1956. - 110с.

4. Богословська $\lambda$. О. Апеляційне провадження: історія виникнення в Україні /А. О. Богословська // Судова реформа в Україні: проблеми і перспективи: Х.: Юрінком Інтер, 2002. - С.206-209.

5. Брынцев В. Д. Судебная власть. Правосудие. Пути реформирования в Украине / В. Д. Брынцев. - Харьков : Основа, 1998. - 140 c.

6. Бережной O.I. Преюдиціальність судових рішень у кримінальних справах. /O.I. Бережной. - Х. СПД. ФО Вапнярчук M.M. 2006. - С. 28.

7. Великий Д. П. Единство и дифференциация уголовно- процессуальной формы : автореф. дис. ... канд. юрид. наук : 12.00.09/ Д. П. Великий. - Москва, 2001. - 20 с.

8. Веретехин Е.Г. Пробелы предварительного расследования и их восполнение в суде 1 инстанции / Е.Г. Веретехин. - Казань. Казанский гос. Ун-ь. 1988. - 160с.

9. Грошевой Ю.М. Нове у кримінально - процесуальному законодавстві України Ю.М.Грошевой, Т.М.Мірошниченко. - Х.: Основа. 2002. - 110с.

10. Гловюк I.B. Кримінально процесуальні функції: теорія, методологія та практика реалізації на основі положень Кримінального процесуального кодексу України /І.В. Гловюк - Одеса: Юридична література. 2015. - 712c.

11. Добровольская Т. Н. Изменение обвинения в судебных стадиях советского уголовного процесса / Т. Н. Добровольская. Москва : Юрид. лит., 1977. - 151 с. 
12. Дроздов О.М. Судові прецеденти - джерела кримінального процесуального права України / О.М. Дроздов/ Актуальні проблеми кримінального права, процесу та криміналістики - Одеса. Фенікс. 2010. -C. 124-127.

13. Зусь А.Д. Механизм правового регулирования. /А.Д.Зусь// Владивосток.: Дальневосточ. Владивост. Ун-т. 1976. - 190с.

14. Ковтун Н.Н. Судебный контроль в уголовном судопроизводстве России. /Н.Н.Ковтун// -Нижний Новгород.: Нижегододская правовая академия. 2002. -332с.

15. Капліна О.В. Кримінальний процес України: підручник / О.В. Капліна,Ю.М. Грошевой, О.В. Шило. - Х. Юрид. університет. 2013. - 820с.

16. Маляренко В. Т. Найпоширеніші помилки та порушення законів, які допускаються при провадженні дізнання і попереднього слідства / В. Т. Маляренко // Право України. - Київ : МЮ України, 2001. - № 3. - C. 15.

17. Овчаренко О.М. Доступність правосуддя та гарантії його реалізації / О.М. Овчаренко: монографія. - Харків. Право. 2008. 280c.

18. Росинский С. Б. Нужен ли предварительный судебный контроль за производством следственных действий в жилище? / С. Б. Росинский. - Российский судья, 2009. - № 8. - С. 17-21.

19. Филин Д.В. Методологические проблемы процессуально-правовых исследований. / Д.В.Филин // Правовой аспект. -Воронеж. ВГУ. № 1. 2007 -С. 129-135.

20. Яновська О.Г. Концептуальні засади функціонування і розвитку змагального кримінального судочинства / О.Г. Яновська: монографія. - К. Прецедент. - 2011 - 308с.

21. Практика Верховного Суду України [електронний ресурс: режим доступу: http:// www.scourt.gov.ua].

\section{References}

1. Alenin Ju. P. Ugolovno-processual'nyj kodeks Ukrainy Nauch. prakt. kommentarij / Ju. P. Alenin. Harkiv : Odisej, 2003. - 959 s.

2. Anciferov K. D. Obvinitel'noe nachalo i anglijskij process / K. D. Anciferov // Juridicheskij vestnik. - Moskva, 1879. - S. 432.
3. Bazhanov M.I. Proizvodstvo doznanija v organah milicii. /M.I. Bazhanov, A.D. Kogan// -H.: 1956. - 110s.

4. Bogoslovs'ka L. O. Apeljacijne provadzhennja: istorija viniknennja v Ukraïni / L. O. Bogoslovs'ka // Sudova reforma v Ukraïni: problemi i perspektivi: H.: Jurinkom Inter, 2002. - S.206-209.

5. Bryncev V. D. Sudebnaja vlast'. Pravosudie. Puti reformirovanija v Ukraine / V. D. Bryncev. - Har'kov : Osnova, 1998. - 140 s.

6. Berezhnoj O.I. Prejudicial'nist' sudovih rishen' u kriminal'nih spravah. /O.I. Berezhnoj. - H. SPD. FO Vapnjarchuk M.M. 2006. S. 28

7. Velikij D. P. Edinstvo i differenciacija ugolovno- processual'noj formy : avtoref. dis. ... kand. jurid. nauk : 12.00.09 / D. P. Velikij. Moskva, 2001. - $20 \mathrm{~s}$.

8. Veretehin E.G. Probely predvaritel'nogo rassledovanija $\mathrm{i}$ ih vospolnenie $\mathrm{v}$ sude 1 instancii / E.G. Veretehin. - Kazan'. Kazanskij gos. Un-'. 1988. - 160s.

9. Groshevoj Ju.M. Nove u kriminal'no - procesual'nomu zakonodavstvi Ukraïni / Ju.M.Groshevoj, T.M.Miroshnichenko. - H.: Osnova. 2002. - 110s.

10. Glovjuk I.V. Kriminal'no procesual'ni funkciï: teorija, metodologija ta praktika realizaciï na osnovi polozhen' Kriminal'nogo procesual'nogo kodeksu Ukraïni /I.V. Glovjuk - Odesa: Juridichna literatura. 2015. - 712s.

11. Dobrovol'skaja T. N. Izmenenie obvinenija $\mathrm{v}$ sudebnyh stadijah sovetskogo ugolovnogo processa / T. N. Dobrovol'skaja. Moskva : Jurid. lit., 1977. - 151 s.

12. Drozdov O.M. Sudovi precedenti dzherela kriminal'nogo procesual'nogo prava Ukraïni / O.M. Drozdov/ Aktual'ni problemi kriminal'nogo prava, procesu ta kriminalistiki - Odesa. Feniks. 2010. - S. 124-127.

13. Zus' L.D. Mehanizm pravovogo regulirovanija. /L.D.Zus'// Vladivostok.: Dal'nevostoch. Vladivost. Un-t. 1976. - 190s.

14. Kovtun N.N. Sudebnyj kontrol' v ugolovnom sudoproizvodstve Rossii./N.N.Kovtun// -Nizhnij Novgorod.: Nizhegododskaja pravovaja akademija. 2002. -332s.

15. Kaplina O.V. Kriminal'nij proces Ukraïni: pidruchnik / O.V. Kaplina, Ju.M. Gro- 


АНОТАЦІЯ
Проведення реборми кримінального проце-
суального законодавства надала нові елементи
побудови кримінального процесу. Визначено, ио
межі судового розгляду пов'язані підготовчим
судовим провадженням. Процесуальні повно-
важення судді, встановлені чинним законодав-
ством відповідають міжнародним правовим
нормам та забезпечують виконання прав, сво-
бод та гарантій учасників кримінального про-
вадження. Межі судового розгляду криміналь-
ного провадження проводиться стосовно обви-
нуваченого відповідно до обвинувального акту.
Зміна обвинувачення може здіиснюватися
публічним обвинувачем.
Запропоновано теоретичні аспекти та
практичне вирішення даних питань та вне-
сення змін до чинного законодавства.
Ключові слова: межі, механізм, статус,
слідчий, прокурор, суддя, обвинувачений, судо-
вий розгляд, вирок.

shevoj, O.V. Shilo. - H. Jurid. universitet. 2013. -820 s.

16. Maljarenko V. T. Najposhirenishi pomilki ta porushennja zakoniv, jaki dopuskajut'sja pri provadzhenni diznannja i poperedn'ogo slidstva / V. T. Maljarenko // Pravo Ukraïni. Kiïv : MJu Ukraïni, 2001. - № 3. - S. 15.

17. Ovcharenko O.M. Dostupnist' pravosuddja ta garantiï jogo realizaciï / O.M. Ovcharenko: monografija. - Harkiv. Pravo. 2008. 280s.

18. Rosinskij S. B. Nuzhen li predvaritel'nyj sudebnyj kontrol' za proizvodstvom sled-
The reform of the criminal procedural legislation is provided new elements of the construction of the criminal process. It is determined that the scope of the trial is related to the preliminary trial. The procedural powers of a judge is established by the current legislation comply with international legal norms and ensure the implementation of the rights, freedoms and guarantees of participants in criminal proceedings. Limits of trial Criminal proceedings are conducted against the accused in accordance with the indictment. A change in charge can be carried out by a public prosecutor.

Theoretical aspects and practical solution of these issues and amendments to current legislation are proposed.

Key words: boundaries, mechanism, status, investigator, prosecutor, judge, accused, trial, sentence.

stvennyh dejstvij v zhilishhe? / S. B. Rosinskij. - Rossijskij sud'ja, 2009. - № 8. S. 17-21.

19. Filin D.V. Metodologicheskie problemy processual'no-pravovyh issledovanij. / D.V.Filin // Pravovoj aspekt. -Voronezh. VGU. № 1. 2007 -S. 129-135.

20. Janovs'ka O.G. Konceptual'ni zasadi funkcionuvannja i rozvitku zmagal'nogo kriminal'nogo sudochinstva / O.G. Janovs'ka: monografija. - K. Precedent. - 2011 $308 \mathrm{~s}$.

21. Praktika Verhovnogo Sudu Ukraïni [elektronnij resurs: rezhim dostupu: http:// www.scourt.gov.ua]. 